\title{
Aboriginal Peoples and the Environmental Movement in Canada: Conflict or Cooperation? ${ }^{1}$
}

\section{Zusammenfassung \\ Indianer und die Umweltschutzbewegung in Kanada: Konflikt oder Kooperation?}

Ziel dieses Artikels ist es, am Beispiel der Red-Squirrel-StraBenblockade in Temagami, Ontario, die vermeintliche Allianz aufzuschlüsseln, die Umweltschutzgruppen und Indianer (First Nations) zum Schutz kanadischer Urwälder eingehen. Kanada gehört weltweit zu den Hauptexporteuren von Holzrohstoffen. Die Forstwirtschaft ist an der Ausbeutung des knappen Weichholzes (softwood) und der Erschließung neuer Waldgebiete interessiert. Für Umweltschutzgruppen steht der Schutz von noch ungenutzten Wäldern (old-growth forests) im Vordergrund, wenn sie angesichts des fortschreitenden Kahlschlages (clear-cut) eine Forststraße blockieren. First Nations dagegen haben umfassendere Ziele als Umweltschutzgruppen, wenn sie auf derselben Straße eine Blockade errichten: Oft findet die Ausbeutung der Wälder auf Gebieten statt, die derzeitigen indianischen Landrechtsforderungen (land claims) unterstehen. Landrechtsforderungen gehen auf die Landrechtsverträge (treaties) zurück, welche First Nations mit der Regierung im letzten Jahrhundert abgeschlossen haben. Heute sind Landrechtsforderungen mit Rückforderungen von Landtitel (aboriginal title) und Ressourcen verbunden, mit dem Wunsch nach ökonomischer Unabhängigkeit und Selbstverwaltung indianischer Reservate (self government) und mit der Anerkennung der Indianer als eigenständige Nation (distinct society). Intakte Wälder sind sowohl Voraussetzung als auch ein Beitrag zur Erlangung ökonomischer Unabhängigkeit.

Am Beispiel der Red-Squirrel-Straßenblockade in Temagami werden Gegensätze zwischen First Nations und Umweltschutzgruppen deutlich. Die Wälder in Temagami sind schutzwürdig, zugleich auch wertvoller Rohstoff für die Wirtschaft, stehen aber auf Land, das zur Zeit der Blockade indianischen Landrechtsforderungen unterstand. Die Positionen der Teme Augama Anishnabai First Nations (TAA) und der Temagami Wilderness Society (TWS) während der RedSquirrel-Straßenblockade zeigen die Schwierigkeit beider Parteien, eine gemeinsame Sprache zu finden, die den Schutz bestehender Wälder gewährleisten könnte.

\section{The Blockades}

In summer of 1993 national and international attention focused on aboriginal people (First Nations) and nonaboriginal environmentalists jointly blocking a logging road which lead to Clayoquot Sound's old-growth rainforest on Vancouver Island, British Columbia. The blockade shed light on a decade-long debate between environmentalists, First Nations and the forest industry over logging the rainforest in Clayoquot Sound. The confrontation was sparked by a decision of the provincial government to protect some of the old-growth forests in Clayoquot Sound from being clear-cut and to limit the size of clear-cuts on the remaining area. However, the protesters - First Nations and environmentalists wanted more of the rainforest on Vancouver Island not to be logged (LEVIN 1993: 21-27).

The event in Clayoquot Sound was not an isolated incident. In the late 1980's and 1990's, similar controversies over protection of old-growth forest took place in British Columbia (South Moresby, Meares Island, Stein Valley, Carmanah Valley) and across Canada (NOTZKE 1994: 100). In Quebec the James Bay Cree cooperated with environmental groups defending their forests from being flooded by damming. In Alberta, the Lubicon Cree allied with the Friends of the Lubicon to prevent logging on their lands (PRATT/URQUHART 1994). The blockade of a logging road by the Teme Augama Anishnabai (TAA) and the Temagami Wilderness Society (TWS) heated up the discussion in Ontario. This province ranks second after British Columbia in controversy over protection of old-growth forest (MORRISON 1993: 25).

Competition for Canada's wilderness, in particular for old-growth forests - forests of old and undisturbed trees that are both ecologically rich and of premium commercial value - has increased since the early 80 's. The forest industry is continuously moving into remaining areas of valuable old-growth forest while environmental groups focus on protecting the same areas. Often First Nations also try to prevent logging of old-growth forests on their land claim areas. Is this, therefore, the perfect alliance between two groups - environmentalists and First Nations - defending their values against industry? Or is it an alliance of limited common interest? The following is an analysis of the Red Squirrel road blockade in the Temagami area in Northern Ontario which involved the TAA and the TWS. I will be looking at the positions of each of the two stakeholders with regard to protection of oldgrowth forest on land claimed by the TAA. The analysis is based both on a historic and legal retrospective of the land claim process which serves as a framework for current land use conflicts between forest industry, First Nations and environmentalists in Southern Canada.

Monika Jäggi, Dr., Department of Geography, York University, 4700 Keele Street, North York, Ontario, Canada 
Aboriginal Peoples in Canada: Aboriginal and treaty rights

To aboriginal peoples, current conflicts over land and resources go back to the treaty signing. Treaties document a history of exclusion for aboriginal peoples with regard to access to resources. Treaties were made between the aboriginal peoples and the federal government in the last century, until 1929, allowing settlement of European settlers on aboriginal land in return for commitments by the government towards aboriginal peoples. From the aboriginal point of view, treaties were based on the understanding of sharing lands and resources with the European newcomers. For the newcomers, however, the treaties defined boundaries and property rights based on European concepts of land ownership. The government was interested in economic development, resource exploitation and land speculation and therefore aimed at relocating aboriginal peoples from their ancestral land.

The government confined them to reserves by negotiating surrender of large areas of their lands (aboriginal title) (BOLDT 1993: 275). Aboriginal title is defined as a right to land that aboriginal peoples possess by virtues of its occupation from time immemorial. Aboriginal title is therefore a form of property right (USHER 1991: 113). In return for surrendering aboriginal title, aboriginal peoples received reserves, small cash payments, annual payments to each person, hunting and fishing gear and promises of access to provincial land for hunting and fishing. Although aboriginal title to land was given up through the treaty signing, the right to hunt and fish for food was still guaranteed through the treaties and was an important part of the agreement (MORRISON 1993: 6). However, treaties were not contracts between equal nations since most treaties were dictated by the newcomers (BOLDT 1993: 275). The unequal relationship was obvious when parks where established in the late 19th/ early 20th century. Many of Canada's parks were created on aboriginal land without consulting aboriginal peoples. Aboriginal peoples dependent on hunting, fishing and trapping were prevented from exercising their treaty rights as soon as a park was established. With the creation of a park the status of the land changed from aboriginal land to parkland under provincial jurisdiction (BERG 1993: 233). There was little appreciation within the governments that parks could be used to support aboriginal peoples and their cultures.

Partly as a result of the non-fulfillment of the treaties by the government, aboriginal peoples are excluded from the Canadian economy today. They are confined to being welfare recipients under federal authority, with overpopulation, unemployment and poverty often characterizing life in aboriginal communities. Under such circumstances the traditional economy of hunting and fishing on provincial land represents an important contribution to survival on reserve.

\section{Self-Government, Land Claims and Aboriginal Interests in Land and Resources}

As part of restructuring of power and responsibility with regard to land and resources, changes were recently introduced in the Canadian legislation allowing land claims and the enforcement of treaty and aboriginal rights (NOTZKE 1994: 5). Consequently, the Supreme Court of Canada recognized for the first time in the 1973 Calder case, that aboriginal title to land existed at the time of colonization as a legal right, derived from the aboriginal people's historical occupation and possession of the land, independent of any treaty (BERG 1993: 229). As a result of this case a federal policy on land claims was established and the return of land or compensation in cash to aboriginal peoples has become possible where treaties had not been fulfilled or in cases where no treaty had ever been signed. In 1982, aboriginal and treaty rights were acknowledged constitutionally for the first time. Aboriginal peoples are therefore the only group in Canadian society who have constitutionally recognized and protected rights to harvest fish and wildlife on provincial land. The acknowledgment of these rights was important since land and resources are regulated by the provinces, and harvesting rights therefore interfere with legislation for provincial parks where usually no hunting takes place. In the 1991 Sparrow case, the Supreme Court of Canada confirmed that those rights could be exercised and that harvesting for food, social and ceremonial purposes was to be given priority over the interest of other user groups as long as conservation of the resources was ensured. ${ }^{2}$ The Sparrow decision was criticized by environmentalists, anglers and hunters, but aboriginal peoples insisted that Sparrow did not create new rights since these rights had been part of the treaties (MORRISON 1993:7).

Today, few of the approximately 600 aboriginal communities across Canada have the land and the resources needed to reach economic independence. Through both the Calder and the Sparrow cases First Nations have gained political momentum which enabled them to seek access to provincial land and resources through land claims. However, First Nations not only seek the implementation of aboriginal and treaty rights, their challenge is to gain political autonomy (self-government) and an official cultural status as a distinct society (BOLDT 1993: 133). A precondition for self-government is achieving economic independence in aboriginal communities. The concept which is sought to lead towards economic independence is local economic development. Since traditional activities still exist in many communities through hunting, fishing and gathering, the concept is based on a combination of those activities with entrepreneurial activities (for example small family businesses involved in tourism, logging or carpentry), the latter supported by government grants (HARRIS 1994: 191). A requirement for both, a traditional economy and business development, is access to off reserve resources on provincial land through land claims and assertion of aboriginal 


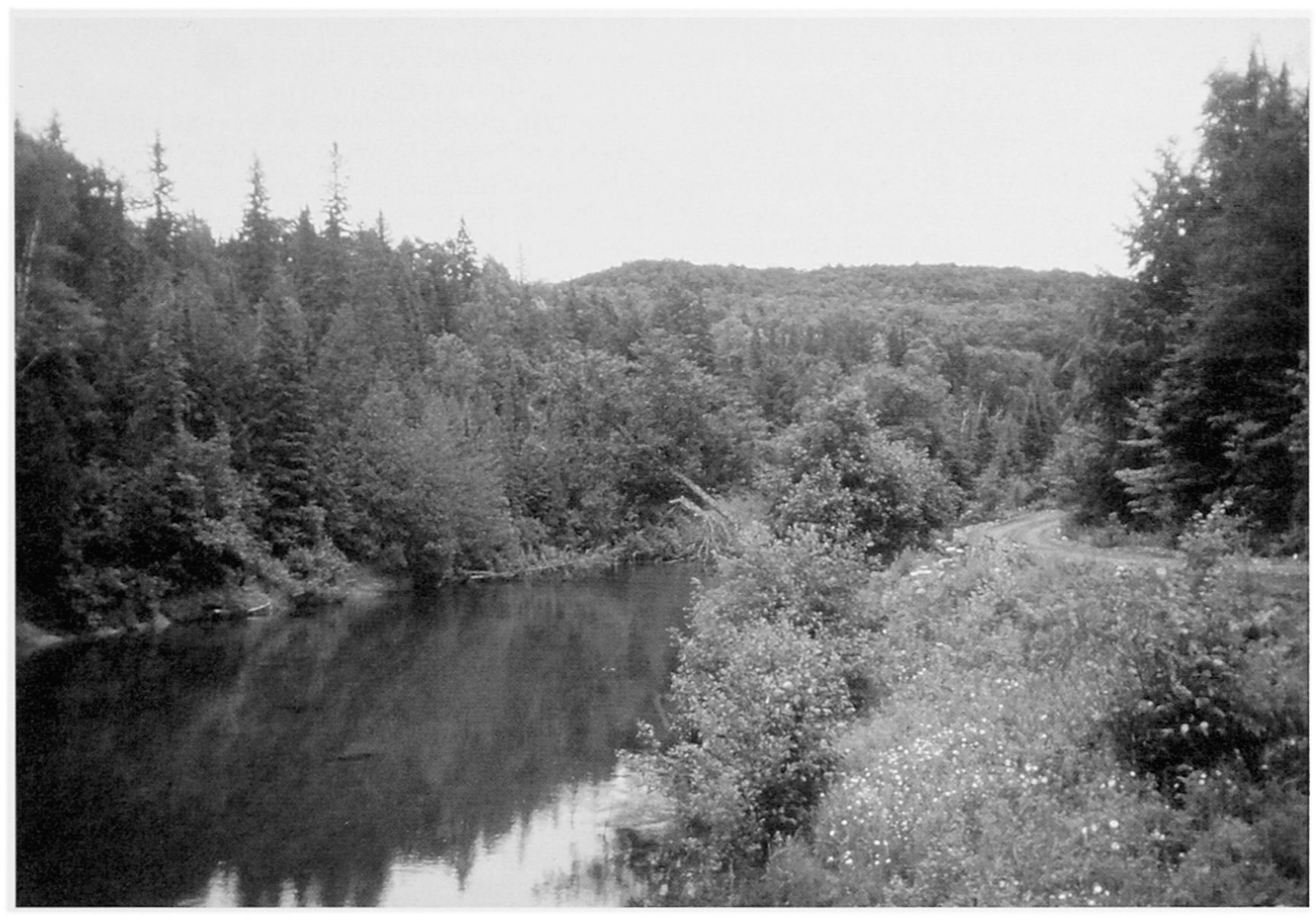

Fig.1 A different approach to forestry in Garden River: Protecting the ecosystem though selection logging. Garden River Indian Reserve, Province of Ontario, June 1995.

Nachhaltige Waldwirtschaft in Garden River. Kein Kahlschlag im Resenvatswald, dafür selektives Fällen auch der Flußufer und damit Schutz des Flusses vor Erosion. Garden-River-Indianerreservat, Provinz Ontario, Juni 1995.

and treaty rights. Land claims are viewed by aboriginal communities as the most important instrument for economic development on reserve. However, First Nations are not alone claiming lands, usually the same lands are also of interest to the forest industry for logging and by environmentalists for protection. This inadvertently leads to land-use conflicts.

\section{Forest Industry and the Boreal Forest in Ontario: Cut and Run}

Canada's forests are its most valuable resource. It covers nearly half of Canada's land mass. Productive forests, which supply timber for pulp, paper and plywood, lumber and other products, occupy 2.2 million square kilometers. Canada is the world's largest exporter of forest products, with a 22 per cent share of all these products traded in world markets. The profit in 1993 was $\$ 37.6$ billion (NOTZKE 1994: 81).
This quote clearly shows the importance of forest industry in the Canadian economy. Until recently, industry harvested softwood species (conifers: spruce, pine) almost exclusively since those provide superior pulp, paper and lumber. However, forest industry is approaching the limit of primary softwood forest resources in Canada. Shortfalls are rooted in harvesting $87 \%$ of the total softwood volume, in exploitative forest practices such as clear-cutting and non-existent or failed attempts at reforestation. Softwood shortages combined with increasing global demand for pulp and paper drives industry continuously into new areas of primary forest, lately the boreal forest which covers 3.24 million square kilometers of Northern Canada or $34 \%$ of the size of Canada (PRATT/URQuHART 1994: 1). The boreal forest contains a mix of hard-and softwood stands (spruce, balsam, fir, trembling aspen, birch) which were never logged before. The stands had been neglected in the past due to the abundance of productive forest in the South and due to the remoteness of the boreal forest from the market. 
The boreal forest has now become the most important source for the pulp and paper industry across the country. Roughly $65 \%$ of Canada's boreal forest is currently under long-term tenure (CANADA'S FUTURE 1994: 5).

Key factors which have facilitated the move to the boreal forest are various long-term tenure systems being granted to forest industry by provincial governments. These systems mirror earlier patterns of exploitative forest management practices. Provincial governments control a majority of the land and forests in Canada. They sign wood supply agreements with industry, allocating the boreal forest to large corporations, which harvest timber and manufacture products. These contracts bind the government for 20 to 25 years to providing an annual supply of wood to each forest company (PRATT/URQUART 1994: 14-17). Since forest management activities are exempted from environmental and socio-economic impact assessments, allocations generally happen before land use decisions are made and without any meaningful public participation (CLARK 1995: 260, HARRIS 1994: 146). In addition, the security of long-term tenure, including financial assistance for road constructions and low stumpage fees (Abholzgebühren), are used to attract companies to invest in the forestry business, providing jobs and revenues. External corporate interests are thus exerting control in the boreal forest.

Forecasts predict that loggers will fell what is left of Canada's accessible forest in the next ten years (MARCHAK 1995). This process is well illustrated in Ontario. As a result of past forest practices, only a tiny fraction of the once dominating white and red pine stands have survived as old-growth forests. These remaining stands are located in Northern Ontario, in the transition zone between the Southern deciduous forest and the boreal forest. Ontario's boreal forest represents the largest untouched wood supply in North America close to American markets, with an estimated value of CDN $\$ 565$ billions. Faced with the loss of premium-quality softwood and jobs the provincial government opened both, the last old-growth pine stands and the boreal forest to industry. The forests have been fully allocated to multinational corporations under long term leases as recently as in 1996. The result is extensive clear-cutting. Environmentalists criticize the government in Ontario as being responsible for what appears to be Canada's largest clear-cut (CANADA'S FUTURE 1994: 20). Clear-cutting will not remedy softwood shortages in the long run since the rate with which forest are cut these days has far outstripped the pace of natural cycles: Under natural conditions, fast growing hardwood (poplar, birch) requiring full sun to grow is overtaken after one generation by slow growing shade tolerant softwood species (spruce, pine). As forests are cut on short rotation (50-60 years), the proportion of hardwood increases while softwood declines, which leads to the conversion of forests from mixed forests to hardwood forests (CARLETON/MacLELLAN 1994). Faced with softwood shortages and encouraged by government to reorganize its mills, the forest industry is changing its focus in the 90's from pulp, paper and lumber to the manufacture of pressed panel board construction using hardwoods. Even industry has recognized the limited time left. But rather than changing forest practices and protecting of old-growth forests the trend, in addition to reorganization, is towards finding new logging sites. Clearly forest policies are directed towards fiber production, not forest protection. As a result not enough is known about oldgrowth forest ecosystems, in particular with regard to white pines. Therefore environmentalists demand a moratorium on logging white pine until the government delivers a policy for old-growth forests protection. Environmentalists also propose to protect the remaining oldgrowth white pines in Ontario. In addition, they suggest to change forest harvesting methods and manage forests with a focus on multiple use values (logging, tourism, recreation, protection) and claim that non-extractive land uses must be determined before resource allocation to industry begins. To ensure public control over land-use decisions the public must also be involved in the decisionmaking process (HUMMEL 1995: 97).

However, some of the white pine stands proposed for protection are likely to create conflict with aboriginal aspirations on land use. This is the case in Temagami, where the old-growth white pines represent both a potential park and the land claim area of the Teme Augama Anishnabai First Nations (WILDLANDS LEAGUE 1996). The white pines also represent the most valuable stand of trees in the area for forest industry.

\section{Temagami - the Red Squirrel Road Blockade}

The Temagami forest marks a transition zone between the conifer-deciduous forests of the South and the boreal forest. Commercial interests in pine forests in Temagami had been high ever since logging started in 1920 . With the exception of 83 old-growth pine stands, all pines have been taken out, leaving only hardwood to grow back (HODGINS/BENIDICKSON 1989: 276). The pines represent the last significant stand of old-growth pine in North America and the last major accessible wilderness in Eastern Canada (POTTs 1989: 207).

Located within this forest is n'Daki Menan, the land of the Teme Augama Anishnabai (TAA). The land covers nearly 10000 square kilometers of forests. Today some 250 people live on 2.6 square kilometers reserve on Bear Island on Lake Temagami. The TAA have been able to mix traditional ways of life with work in the formal sector drawing on the nearby forest for game, fish, berries, maple sugar, water, medicines, wood for heating and construction and for the means of communicating with ancestors and spirits. The main threat to these activities is the loss of habitat through logging. Jobs in the formal sector are based on wood-workings sold in the nearby town of Temagami, as well as carpentry and outfitting/guiding for tourists. A lack of capital and access to markets have prevented these efforts to become long-term sources of income (HARRIS 1994: 197). 
Since the TAA and their lands were not included in the 19 th century treaties, the TAA wanted to gain back control over their land and obtain an economically adequate land base through the settlement of their land claim. However, in 1984 the TAA lost their land claim before the Supreme Court of Ontario (POTTS 1989: 201). While the land claim was being negotiated, clear-cut logging accelerated in the area dispite a land caution. The caution was set in place by the TAA to freeze all development in the area as long as the land claim negotiations where under way (LARONDE 1993: 96).

After the Supreme Court had denied the TAA Aboriginal right to their land, the band brought their case to the Ontario Court of Appeal in 1988. Meanwhile the provincial government announced the extension of the Red Squirrel logging road to provide logging companies access to the old-growth forests in n'Daki-Menan. The forest industry argued that the road extension was essential to maintain supplies of timber and jobs. The government based its decision on an environmental assessment which focused solely on the impact of the road construction. The assessment did not consider the impact of logging on the forest since forestry is excepted from assessments. Despite record numbers of requests for environmental hearings, the road construction went ahead without public or aboriginal consultation (HARRIS 1994: 118, 140 ). Since the pines on the land claim area were too valuable to be left to the TAA, clear-cutting was thus allowed by the government before the Court of Appeal had reached a decision about the land claim (BRAY/THOMSON 1990: 130). The TAA denounced the road extension as a violation of their as yet unresolved land claim. They unsuccessfully sought a court injunction to stop road building and clear-cutting based on the fact that logging would cause irreparable damage to land and to their ability to exercise treaty rights and to proceed with local economic development (UNION OF ONTARIO INDIANS 1996).

While the TAA were in court, seeking an injunction, the TWS, a Toronto-based environmental group, mounted a blockade on the Red Squirrel road. The environmentalists' goal was to protest government procedures for approving the road, to prevent road construction and to protect a unique wilderness through declaration of a Temagami wilderness area. With their legal routes exhausted, the TAA also resorted to blocking the Red Squirrel road, however, first evicting the TWS since they had been occupying aboriginal land for their purposes without owning the land.

When the Court of Appeal decided against the TAA's claim in 1989, the TAA signed a bilateral agreement with the province in an attempt to at least negotiate resource management on their lost lands. The purpose of the agreement was to negotiate a Treaty of coexistence which would establish the sharing of responsibility for land and resource management in the Temagami area based on the concept of comanagement - the sharing of control between government and First Nations over land and resources. The agreement also aimed at the protection of the TAA's aboriginal and treaty rights. Meanwhile, no timber harvesting would take place and the Red Squirrel road would not be used by logging trucks (BRAY/THOMSON 1990: 136). As part of the agreement, the TAA presented their perceptions on forest management, including plans for protection of cultural and heritage trails and other significant places such as archaeological or spiritual sites and part of the old-growth forest. They also recommended using old-growth forest according to aboriginal principles which emphasized no clear-cutting, small-scale operations and reforestation. These practices allow for multiple forest use, such as exercising treaty rights and a traditional way of life. In addition, First Nations wished to exercise community participation in future forest planning and management (TEME AUGAMA ANISHNABAI 1992).

However, the treaty of coexistence between the government and the TAA did not work out (CULLINGHAM 1996: 16). Therefore the 23-year old caution which prevented development in the area (with the exception of logging) was lifted and the government now proceeds to open the area to further exploitation. With regard to the oldgrowth white pines, 61 out of 83 stands are scheduled for logging, starting in September 1996 (COMPREHENSIVE PLANNING COUNCIL 1996). As a consequence of this decision the Temagami Wilderness Society (today Earthroots) has announced blockades, independent of the First Nation, to protest further logging of white pines.

\section{Alliances?}

One might wonder why joint action between the two groups has been weak during the blockade in Temagami. An alliance between the TAA and the TWS would have seemed natural since logging happened in forests both parties were dedicated to protect from being exploited. However, not only did the parties mount two separate road blockades, they disagreed over priority of interests and the question whether aboriginal rights were more important than wilderness protection or vice versa?

The TAA blockade took place in the context of an unresolved land claim. To the First Nation the priority lay in settling their claim, having their aboriginal and treaty rights recognized, and ultimately, to get ownership and control over land and resources. The blockade by the TAA was therefore not caused by opposition ${ }^{3}$ to forest operations alone but by their desire to be recognized as both an economical and political factor and their fear that forests would be exploited at such a rapid rate that the resource will be exhausted before land claim settlement will be reached. Old-growth forest protection was only part of a larger political question. The TWS on the other side was concerned with the protection of the trees and not with the First Nation's broader goals. Faced with the pressures of urbanization and industrial development, environmentalists see aboriginal political interests as secondary to the survival of wildlife and natural areas. 
Therefore, the political agenda of environmental groups often does not include aboriginal rights and considers aboriginal peoples as stakeholder groups (UNION OF ONTARIO INDIANS 1996).

In light of land claim settlements, one of the biggest concerns of environmentalists are pro-development trends in aboriginal communities (UNION OF ONTARIO INDIANS 1995). What would happen, environmentalists ask, if aboriginal people gained title to old-growth forests and decided to log the forest themselves (MARCHAK 1995: 107)? Environmentalists anticipate that if First Nations succeed in settling land claims, they would emphasize short-term profits. This scenario can not be excluded. However, First Nations such as the TAA have repeatedly indicated that there is a commitment to sustainable forestry, if not explicit protection. The commitment to sustainable forestry also appears in forestry plans worked out by other individual First Nations such as the Nisga'as or the Algonquins of Barriere Lake as well as in the Aboriginal Forest Land Management Guidelines (SMITH 1995). Aboriginal communities such as the Wikwemikong in Ontario already practice sustainable forestry based on above-mentioned principles (ANISHINABEK NEWs 1996).

Another sensitive topic to both parties concerns the creation of new parks on land claim areas. In the process of negotiating land claims, wilderness protection is not moving forward. But time is precious. Continuing resource exploitation may not leave much to protect once a claim has been settled. Therefore environmental groups demand that land claim negotiations move faster. However, First Nations have made it clear that they are opposed to park creation on their land before claims are settled since reserving land for parks may compromise their aspirations (HUMMEL 1998: 93). After a claim has been settled, First Nations wish to be involved in the planning of a proposed park from the beginning. First Nations want the public to realize that comanagement of parks is not a threat but a guarantee of their traditional life and a contribution to protection of wilderness areas.

Another trend which is of great concern to environmentalists are aboriginal activities in parks, in particular with regard to non-traditional hunting techniques. A view often held by environmentalists is that First Nations could be permitted to continue their subsistence activities within a park as a part of their traditional life, provided they adhere to traditional methods of harvesting such as using snowshoes or canoes and bow and arrow instead of boats, snowmobiles and guns. Aboriginal peoples, however, do not share the antipathy felt by environmentalists towards technology - including mechanized forms of wilderness travel, since boats, snowmobiles and guns are not used for recreation as in the non-aboriginal society, but for exercising their treaty rights (MORRISON 1993: 5).

In the past, communication between First Nations and environmental groups has been poor and there is no common environmental policy in place. Too many con- troversial or unknown views have lead to mutual mistrust (UNION OF ONTARIO INDIANS 1996). It appears, however, that there is common ground for First Nations and the environmental movement: it is the demand for a community-based form of control and for participation in the government decision-making process with regard to land and resource use. These common grounds could become more important with regard to future wilderness protection, where some of the proposed areas will fall under aboriginal jurisdiction and more and more parks will become the subject of land claims. George Erasmus, former Chief of the Assembly of First Nations, points out that "The firm view of the aboriginal leadership is that we would be much more inclined to support conservation policies and practices, including parks, if our basic rights were first legally recognized and respected" (HUMMEL 1989:5). In the view of First Nations, political support for land claims by environmental groups would enable aboriginal peoples to proceed with negotiating land claims and self-government and give them the possibility to implement alternative land use policies.

After years of controversy between the two parties, some environmental groups started broadening their agenda, approaching First Nations and trying to come to terms with the different perceptions on wilderness protection (UNION OF ONTARIO INDIANS 1996). However, with several issues yet unresolved it remains to be seen whether and how the struggle for future wilderness protection in Southern Canada will unify First Nations and environmentalists.

\section{Notes}

1 This paper is based upon literature- and field research supported by the Swiss National Science Foundation, under Grant 8210-040205. I thank the Union of Ontario Indians for supporting my research.

${ }^{2}$ Algonquin provincial park in Ontario was created in 1893 and today represents the land claim area of the Golden Lake First Nation. While their land claim was being negotiated, the provincial government implemented Sparrow, signing an interim agreement with the First Nation. The agreement allowed supervised hunting in and snowmobile access to the park. Environmentalists protested the move by government to grant the First Nation their treaty rights and motorized access to a protected area (MORRISON 1993: 1-2).

${ }^{3}$ The First Nation involved in the Clayoquot Sound campaign was not necessarily opposed to logging as were the environmentalist, since unemployment rates within the band was between 60 and 70 percent and the band desperately needed economic opportunities. Their motivation to collaborate with the environmentalists was to stop logging in Clayoquot Sound until their land claim was settled. Yet more than two years of international attention and working with environmentalists has not resulted in the settling of their claim nor did it create any jobs or improved their economic situation (LEVIN 1993: 25). 


\section{Literature}

ANISHINABEK NEWS (1996): Published by the Union of Ontario Indians. 8 (5). North Bay.

BERG, L., et al. (1993): The Role of Aboriginal Peoples in National Park Designation, Planning, and Management in Canada. In: DEARDEN, P., ROLLINS, R. (eds.). Parks and Protected Areas in Canada, Planning and Management. Toronto.

BOLDT, M. (1993): Surviving as Indians: The Challenge of Self-Government. Toronto.

BRAY, M., and THOMSON, A. (eds.) (1990): Temagami. A Debate on Wilderness. Toronto.

CANADA'S FUTURE FOREST ALLIANCE (1994): Brazil of the North. British Columbia.

CARLETON, T. J., MacLELLAN, P.(1994): Woody Vegetation Responses to Fire Versus Clear-Cut Logging: A Comparative Survey in the Central Canadian Boreal Forest. In: Ecoscience. $1(2)$.

CLARK, T. (1995): Timber Supply and Endangered Spaces: A World Wildlife Fund Canada Discussion Paper, World Wildlife Fund Canada, Toronto.

COMPREHENSIVE PLANNING COUNCIL (1996): Report of the Comprehensive Planning Council on Land Use for the Temagami Comprehensive Planning Area. April 10, 1996. Ministry of Natural resources. Ontario.

CULLINGHAM, J. (1996): Temagami on the Brink: In: NOW. April 25 to May 1, 1996. Toronto.

HARRIS, J. (1994): Development Alternatives, a Whole Economic Perspective. Ph. D. Thesis. Department of Geography. University of Waterloo. Canada.

HODGINS, B. W., BENIDICKSON, J. (1989): The Temagami Experience. Recreation, Resources and Aboriginal Rights in Northern Ontarios Wilderness. Toronto.
HUMMEL, M. (ed.) (1995): Protecting Canada's Endangered Spaces. An Owner's Manual. Toronto.

LARONDE, M. (1993): Comanagement of Lands and Resources in n'Daki Menan. In: Mawhinney Anne-Marie (ed). Rebirth: Political, Economic and Social Development in First Nations. p. 93-106. Toronto.

LEVIN, B. (1993): Tree Huggers Confront Tree Cutters on Vancouver Island. In: MacLEAN'S. Canadas Weekly Magazine. August 16: 21-27.

MARCHAK, P. (1995): Logging the Globe. Montreal/ Kingston.

MORRISON, J. (1993): Protected Areas and Aboriginal Interests in Canada. A World Wildlife Fund Canada Discussion Paper. Toronto.

NOTZKE, C. (1994): Aboriginal Peoples and Natural Resources in Canada. North York.

POTTS, G. (1989): Teme Augama Anishnabai. In: BOYCE, R. (ed.) Drumbeat - Anger and Renewal in Indian Country. Toronto.

PRATT, L., URQUHART, I. (1994): The Last Great Forest. Japanese Multinationals and Alberta's Northern Forest. Edmonton.

SMITH, P., SCOTT, G., MERKEL, G. (1995): Aboriginal Forest Management Guidelines. A Community Approach. National Aboriginal Forestry Association. Ottawa.

TEME AUGAMA ANISHNABAI (1992): Presentation to Class Environmental Assessment for Timber Management Plan in Ontario, Exhibit 10.

UNION OF ONTARIO INDIANS (1995): Conference on Economic Development in Native Communities. North Bay May 5-7.

UNION OF ONTARIO INDIANS (1996): Personal Interviews. North Bay. March 19-20, 1996.

USHER, P. (1991): Some implications of the Sparrow Judgment for Resource Conservation and Management. In: Alternatives. 18(2): 20-21.

WILDLANDS LEAGUE (1996): Map On Northern Ontarios Endangered Spaces. Toronto. 